ACTA UNIVERSITATIS LODZIENSIS

FOLIA LITTERARIA POLONICA 2(40) 2017

http://dx.doi.org/10.18778/1505-9057.40.01

Joanna Orska*

\title{
„Najciekawsza wydaje mi się właśnie osobność" (Charles Reznikoff i przekłady Piotra Sommera) $^{1}$
}

Na początku lat dziewięćdziesiątych, w krakowskim „NaGłosie” opublikowano dużą rozmowę, zatytułowaną Literatura jest tłumaczeniem. Brali w niej udział: Ryszard Krynicki, Czesław Miłosz, Marian Stala, Jerzy Illg, Bronisław Maj (ze strony redakcji) oraz Piotr Sommer - jako tłumacz poezji amerykańskiej, przede wszystkim zaś sprawca - jak to ujmuje w jednym z pytań Stala - epidemii „o’haryzmu” 2 . Wbrew hasłu, pod którym odbywała się dyskusja, większość tez świadczyła na rzecz nieprzekładalności tekstu z obcego języka; sama możliwość przenikalności językowych światów, pojęta inaczej niż w kategoriach konsumpcji obcości, została właściwie wykluczona ${ }^{3}$. Wyjątek w gronie wypowiadających się na rzecz swoistej nienaruszalności gmachu polszczyzny, polskiej kultury, stanowił Piotr Sommer - rzecznik pewnej przezierności granic pomiędzy językami. Przekraczanie tych granic nie odbywałoby się jednak przy udziale utopii języka uniwersalnego (Goetheańskiej Weltliteratur), stano-

* Dr hab., Instytut Filologii Polskiej Uniwersytetu Wrocławskiego, Zakład Literatury Polskiej po 1918 r., pl. Nankiera 15, 50-140 Wrocław; joanna.orska@uwr.edu.pl.

${ }^{1}$ Tekst powstał w ramach pracy nad projektem grantowym „Nauka chodzenia”. Świadomość późnonowoczesna $w$ metapoetyckich wypowiedziach przedstawicieli polskiej neoawangardy lat 60. i 70. XX wieku (11H 130651 82) 0064/NPRH3/H11/82/2014. Cytat w tytule pochodzi z wypowiedzi Co robi zdanie? Piotr Sommer w rozmowie z Zofią Zaleską, „Kwartalnik Artystyczny” 2015, nr 3, s. 43.

${ }^{2}$ Literatura jest tlumaczeniem, rozmowę z R. Krynickim, Cz. Miłoszem i P. Sommerem przeprowadzili B. Maj, J. Illg, M. Stala, „NaGłos” 1993, nr 11. Przedr. w: Cz. Miłosz, Rozmowy polskie 1979-1998, Wydawnictwo Literackie, Kraków 2006.

${ }^{3}$ Tomasz Bilczewski, odnosząc się do historii komparatystyki, najbardziej zachowawczą jej gałąź, powiązaną z XIX-wieczną literaturą francuską i XIX-wiecznym nacjonalizmem, a kojarzoną z tradycyjnym pojęciem „wpływu” - określa mianem strategii inkorporacyjnej: ,[...] środek ciężkości komparatystycznej analizy spoczywa na dziełach rodzimej tradycji (punkt wyjścia), a komparatystyczny komponent zostaje włączony, [...] przede wszystkim po to, by lepiej oświetlić - co często oznacza: pozytywnie zwaloryzować - teksty wybrane z narodowego inwentarza literackiego" (T. Bilczewski, Komparatystyka i interpretacja. Nowoczesne badania porównawcze wobec translatologii, Wydawnictwo Universitas, Kraków 2010, s. 60). W dyskusji „NaGłosu” większość osób biorących w niej udział, operujących pojęciami upowszechnionej translatologicznej publicystyki, zdradza właśnie takie podejście. 
wiącego swoisty kanon komunikacyjny, gwarantujący odpowiedniość znaków, nazw czy konstrukcji składniowych obcych sobie języków. W autokomentarzach dotyczących tłumaczenia Sommer przemawia w tonie o wiele mniej steoretyzowanym, bliższym kategoriom intuicyjnie rozumianego poetyckiego warsztatu, mówiąc na przykład o „nauce” - o tym, czego Miłosz nauczył się od Amerykanów, Krynicki od Bertolda Brechta, Zagajewski od Josifa Brodskiego. „Nauka” - nazywana przez Sommera gdzie indziej „uwewnętrznieniem języka”4 - wygląda na kategorię do pewnego stopnia Derridiańską: ofiarowania czegoś w sposób niejednoznaczny, bez możliwości prawdziwego daru - a wypowiedzi tego właśnie filozofa dotyczące przekładów wydają się szczególnie bliskie poglądom tłumacza5. Jeżeli odejmiemy „nauce” jej umocowanie w określonym kanonie, powiązanym ze zinstytucjonalizowanym aspektem władzy, stanie się ona funkcją społeczną, czy też lepiej - pewnym zachowaniem, transponującym nieokreślone wprost wartości, rejestry nadawania i rozumienia, rejestry znaczeń, w związku z pewnym chcianym pokrewieństwem - czy jak powiedziałby autor - ,pobratymstwem języka i wrażliwości” (UWB, 12). W taki właśnie sposób chciałabym zapytać o to, czego Piotr Sommer, jeden z najbardziej istotnych

${ }^{4}$, ,[...] tylko język nieuwewnętrzniony jest naprawdę językiem cudzym, czyli obcym. Tę dodatkową wiedzę i dodatkowy rodzaj czucia, jakie można zyskać przez nową przyjaźń, da się z powodzeniem ulokować po stronie korzyści: z nauki o językach porozumienia - czyli o znaczeniach $\mathrm{i}$ ich melodiach - chyba nigdy nic bardzo złego nie wynikło" (P. Sommer, Ucieczka w bok (Pytania i odpowiedzi), Biuro Literackie, Wrocław 2010, s. 38-40). Dalej oznaczam w tekście jako UWB.

${ }^{5}$ Idea przekładalności neutralizuje „nacjonalizm” języka. W eseju Wieże Babel (pol. przekład A. Dziadek, w: Współczesne teorie przekładu. Antologia, red. P. Bukowski, M. Heydel, Znak, Kraków 2009, s. 375-383) Derrida, reinterpretując Zadania tlumacza Benjamina, za którym przyjmuje koncepcję tłumaczenia jako sposobu przetrwania, ,przeżycia” języka, przyrównuje przekład do pewnej formy „dawania”, przedłużania istnienia oryginału i odnowy jego istnienia w pewnej, nowej wspólnocie. W akcie przekładu dochodzi więc do rozszerzenia oryginału poza możliwości rodzimej wspólnoty, choć jednak, jako przełożony, istnieje on zupełnie inaczej, pozostając w gruncie rzeczy nieprzekładalny. W tomie rozmów z francuskimi i amerykańskimi badaczami, The Ear of the Other, Derrida rozwija swoje myśli o przekładzie, mówiąc, że tym, co jest ,nieprzekładalne” pozostaje lingwistyczna różnica zapisana w języku. W jednym systemie językowym zawartych jest w istocie wiele języków, subsystemów; samo istnienie czegoś takiego, jak ,jeden język” jest w istocie wątpliwe (The Ear of the Other. Otobiography, Transference, Translation, red. Ch. McDonald, Schocken Books, New York 1985, s. 100). U początku rozważań Derridy stoi ten zasadniczy brak, który charakteryzuje każdy oryginał i który stanowi immanentną kondycję znaczenia. Nie ma języków „czystych”, a w procesie tłumaczenia transformacji ulega zarówno oryginał, jak i przekład, tłumaczenie zaś stanowi rodzaj kontraktu zakładającego „przeżycie” języków - nie kanonu, tekstu, autora (rozmawiający z Derridą badacze odnosili się wcześniej do jego tekstu Living On/ Borderlines, zamieszczonego w zbiorze Deconstruction and Criticism z 1979). Benjamin chciał, aby ta możliwość tłumaczenia zasadzała się na swego rodzaju „pokrewieństwie” (a może „pobratymstwie” języków) - Derrida zastrzega jednak, że nie możemy o tym myśleć w sensie historii czy rodzin języka. Chodzi o czysto „językowe” pokrewieństwo; zasadzające się na samym byciu języka językiem, który - poprzez zakładaną przetłumaczalność - niesie ze sobą pewną obietnicę całości, obietnicę komunikacji (J. Derrida, dz. cyt., s. 123-124). 
dla polskiej liryki ostatniego dwudziestolecia twórców, „nauczył się”, tłumacząc do niedawna słabo rozpoznawanego amerykańskiego modernistę o żydowskich korzeniach - Charlesa Reznikoffa.

W Ucieczce $w$ bok Sommer wspomina swój pierwszy kontakt z wierszem Reznikoffa - chodziło o lekturę tekstu Miltona Hindusa opublikowanego w „New York Times Books Review” w 1976 roku, po śmierci poety. Razem z tekstem zamieszczono wiersz Kaddish, poświęcony pamięci jego matki - na punkcie którego to tekstu, jak relacjonuje Barbarze Łopieńskiej, „,ostał całkowitego hopla" (UWB, 15). W tejże rozmowie polski autor zwierza się, że tłumaczy Reznikoffa już od dwudziestu lat, co - jako że rozmowa odbyła się prawie dziesięć lat temu, w 1996, a zapowiedziany, rozszerzony tom tłumaczeń Reznikoffa ma się dopiero ukazać - wskazuje na jednego z najdłużej towarzyszących doświadczeniom twórczym Sommera poetów ${ }^{6}$. Reznikoff jest zresztą najczęściej, obok Brechta i Konstandinosa Kawafisa, przywoływanym przez polskiego autora źródłem inspiracji. Oprócz specyficznej strategii budowania poetyckiego zdania, o której mówi Sommer Łopieńskiej przy okazji refleksji nad Kaddishem Reznikoffa - decydujące w przypadku tej sympatii byłoby zainteresowanie tłumacza dla tego, co marginalne (dla języków, pomysłów i tendencji nie znajdujących sobie miejsca w głównym nurcie literatury). Przychylność dla tego, co inne, obce, zmarginalizowane, znajduje wyraz w większości translatorskich czy w ogóle czytelniczych wyborów Sommera: tłumaczył wszak z jednej strony poetów z szeroko rozumianego pogranicza brytyjskości, Irlandczyków i Szkotów posługujących się angielszczyzną mocno zdeterminowaną przez lokalne, etniczne akcenty i smaki - z drugiej strony zaś przedstawicieli otwarcie i z wyboru niemainstreamowej, zbuntowanej wobec uniwersytetów poezji amerykańskiej. Obiektywiści to amerykańska grupa awangardowa (poza Sommerowymi tłumaczeniami Reznikoffa i wzmianką w Historii Literatury Amerykańskiej $X X$ wieku) w Polsce właściwie nieobecna. Także w Stanach przez długi czas nie budziła większego zainteresowania. Sam Charles Reznikoff był synem rosyjskich uchodźców, którzy opuścili kraj w ucieczce przed pogromami, będącymi następstwem zabójstwa cara Aleksandra II Romanowa. Reznikoff urodził się na Brooklynie - studia prawnicze i dziennikarskie, krótka służba w amerykańskim wojsku mogły świadczyć na rzecz asymilacji poety z amerykańską społecznością i jej kulturą. W dzieciństwie był świadkiem przybycia swoich dziadków do Ameryki (uciekali przed kolejną falą prześladowań) i doświadczył licznych

\footnotetext{
${ }^{6}$ Pierwszym wyborem poezji Reznikoffa w tłumaczeniu Sommera było wydane w 1991 roku Graffiti. 67 wierszy z lat 1920-1975 (SDK, Sanok 1991). Późniejsze wybory wierszy ukazują się w złożonych przez Sommera antologiach współczesnej poezji amerykańskiej w: Artykułach pochodzenia zagranicznego (Wydawnictwo Marabut, Gdańsk 1996, tam wiersze Reznikoffa i szkic o nim znajdują się na stronach 347-412) i O krok od nich (Biuro Literackie, Wrocław 2006; wiersze na stronach 11-68). Cytaty z ostatniego z tych źródeł oznaczam jako OK.
} 
aktów antysemityzmu zarówno w swojej rodzinie, jak i osobiście - co stanowi jeden z ważnych tematów jego twórczości. W latach trzydziestych z Georgem Oppenem i Louisem Zukofsky’m założył wydawnictwo Objectivist Press, w którym opublikował kilka pierwszych książek. Wydawnictwo prowadzone przez Oppenów powstało w następstwie słynnego, obiektywistycznego manifestu autorstwa Zukofsky'ego: Sincerity and Objectification. With a Special Reference to Charles Reznikoff, który ukazał się w 1931 roku, na łamach prominentnego czasopisma „Poetry”, wydawanego w Chicago przez Harriet Monroe. Od 1918 roku przez następne sześćdziesiąt lat Reznikoff opublikował kilka opowiadań, dziewięć sztuk, liczne tłumaczenia; pisał także i przygotował do edycji prace historyczne oraz (najczęściej własnym sumptem, sam składając swoje książki) dziewiętnaście tomów poezji. W eseju biograficznym, poświęconym twórczości Reznikoffa, Milton Hindus zaznacza, że dopiero ukończywszy siedemdziesiąt siedem lat, w roku 1971, poeta został rozpoznany jako dość istotna postać amerykańskiego świata literatury. Nagrodzono go wówczas niewielką nagrodą Morton Dauwen Zabel, przyznawaną przez Narodowy Instytut Sztuki i Literatury. Przez całe życie Reznikoffa nie ukazał się ani jeden tom jego wierszy zebranych, jego nazwisko nie figurowało też w ważnych wyborach prezentujących nową amerykańską poezję ${ }^{8}$.

Jak pisze Stephen Fredman, jedyny jak dotąd monografista poety, „Poezja Reznikoffa była prawdopodobnie niezwykle trudna do dostrzeżenia dla krytyków jak Kenner czy Bloom; to poezja, która rozgrywa się na naszych oczach, nie zaprasza ani do rozwikływania referencjalnych zagadek ani do interpretacji ukazujących psycho-dynamiczny agon"9. Dla Harolda Blooma Reznikoff był pomniejszym poetą żydowskim, ponieważ nie używał stylu profetycznego, właś-

${ }^{7}$ L. Zukofsky, Sincerity and Objectification. With a Special Reference to Charles Reznikoff, „Poetry” 1931, nr 5, s. 272-285, http://www.jstor.org/stable/20577923 [dostęp: 10.11.2014].

${ }^{8}$ Jak pisze Milton Hindus, pierwszy przegląd wierszy Reznikoffa, By the Waters of Manhattan, ukazał się w 1962 roku nakładem New Directions i rozbudził w pewnym stopniu zainteresowanie poetą; późniejsza publikacja pierwszego tomu Testimony. The United States 1885-1890 spotkała się jednak z reakcją negatywną bądź milczeniem, także oficyna zaniechała dalszego wydawania Reznikoffa, a on sam raz jeszcze został skazany na własne wydania (w ten sposób wyszedł drugi, nieskończony tom Testimony. The United States 1891-1900, w 1968). Dopiero w 1974 roku małe wydawnictwo The Black Sparrow Press wzięło poetę pod swoje skrzydła, wydając najpierw tom zatytułowany By the Well of Living and Seeing. New and Selected Poems 1918-1973 i w 1975 roku Holocaust, w miękkiej oprawie. Reznikoff wprowadzał poprawki do pierwszego tomu Complete Poems jeszcze w 1976 roku, w którym zmarł. M. Hindus, Epic, Action-Poem, Cartoon. Charles Reznikoff's Testimony. The United States 1885-1915, w: Charles Reznikoff. Man and Poet, ed. M. Hindus, National Poetry Foundation, University of Maine at Orono1984; podaję za źródłem: http://www.english.illinois.edu/maps/poets/m_r/reznikoff/testimony.htm [dostęp: 9.10.2015].

${ }^{9}$ S. Fredman, A Menorah for Athena. Chäles Reznikoff and the Jewish Dilemmas of Objectivist Poetry, University of Chicago Press, Chicago and London 2001, s. 11. Dalej w tekście jako MFA. Tłumaczenia z tego źródła J.O. 
ciwego dla ulubionego przezeń romantyzmu; dla Hugh Kennera z kolei, tak jak i inni obiektywiści, pozostawał pomniejszym modernistą, zaledwie naśladowcą wielkiego Ezry Pounda. Cechy skromnego stylu autora Jerusalem the Golden: naga struktura wydarzeń ukazanych w możliwie najbardziej przejrzysty sposób, skrupulatna uwaga skupiona na detalu - słowa, poetyckiej linii czy przedmiotu przedstawienia - stanowiły dobitny przykład poetyckiej „,szczerości”, w związku z którą Zukofsky właśnie jemu poświęcił całość swojego słynnego, obiektywistycznego manifestu ${ }^{10}$. Nakazowi jasności wyrazu u Reznikoffa towarzyszyła tendencja do elizji, dążenie do zwięzłości, ale i gęstości tekstu; jak komentuje Fredman: „to, co rozgrywa się na naszych oczach nie musi być w pełni oczywiste” (MFA, 11-12). Ważnym aspektem poezji Reznikoffa pozostaje także jej etyczny wymiar, ujawniający się dyskretnie - jako zobowiązanie względem Innego. Choć istotnym tematem i motywem tej twórczości pozostaje antysemityzm, nie jest ona w tak otwarcie zideologizowany sposób żydowska, jak ta uprawiana przez żonę poety, Marie Syrkin, powiązaną przez całe życie z ruchem syjonistycznym ${ }^{11}$. Jak pisze inny krytyk towarzyszący Reznikoffowi, Ranen Omer-Sherman, antytysemityzm stematyzowany zostaje przez poetę umiejętnie, włączony do prawie beznamiętnie relacjonowanej autobiografii; internalizacja stereotypów rasowych do wewnątrz wiersza przynosi efekt w postaci patronującego wyborowi tematów

${ }^{10}$ Sincerity ('szczerość') to kategoria zaczerpnięta ze słownika Poundowskiego. W A Retrospect Pound pisał: „Wierzę, że technika jest sprawdzianem szczerości człowieka; jeżeli chodzi o prawo, wtedy kiedy jest sprawdzalne; w zrównaniu z ziemią każdej konwencji, która zaciemnia lub wstrzymuje od wykonania precyzyjne wypełnienie płynącego stąd impulsu" (E. Pound, $A$ Retrospect, w: tegoż, Pavannes and Divisions, Knopf, New York 1918, s. 103, https://archive.org/stream/cu31924021664408\#page/n127/mode/2up/search/a+retrospect [dostęp: 3.01.2018]; thum. moje).

${ }^{11}$ Marie Syrkin była córką Bassyi Osnos Syrkin, feministycznej rewolucjonistki i syjonistki, oraz Nahmana Syrkina przywódcy i lidera Syjonizmu Socjalistycznego, którego idee zainspirowały ruch kibucowy. Syjoniści w Stanach Zjednoczonych budowali alternatywną - pionierską, silną, opartą na narodowym terytorializmie - polityczną koncepcję tożsamości żydowskiej po Holokauście, wobec wzorca asymilacyjnego z jednej strony i tradycji diasporycznej, przywiezionej jako swego rodzaju dziedzictwo przeszłości przez żydowskich uciekinierów z Europy - z drugiej. Pomiędzy rozmaitymi opcjami ideowymi istniał jednak żywy i otwarty dialog; Syrkin pisywała do „Menorah Journal”, którego redakcja (stanowiąca uniwersytecką, oświeconą, umiarkowaną politycznie elitę) przejawiała tendencje asymilacjonistyczno-diasporyczne, a którego autorem i poetą był jej mąż, Charles Reznikoff. Ten ostatni z kolei pracował na rzecz syjonistycznej „Jewish Frontier", pomagając w edycji pisma, ratując się tym samym w trudnej sytuacji finansowej. Reznikoff pozostawał przeciwny nacjonalistycznym przesłankom syjonizmu. W A Menorah for Athena Stephen Fredman opisuje uniwersytecki Menorah Movement lat trzydziestych jako kulturalną platformę formułującą ideał żydowskości w Stanach wobec tej radykalnej, nacjonalistycznej idei, nakazującej Żydom eksodus do ich nowego, własnego państwa - Izraela. Reznikoff był zaangażowany w prace „Menorah Magazine”; było to pierwsze miejsce, w którym miano opublikować manifest obiektywistyczny Zukofsky'ego, który został w końcu odrzucony przez redakcję ze względu - jak to ujęto - na mętny i pełen błędów język. 
nakazu etycznego, z konieczności kształtującego przedstawienie ${ }^{12}$. Pejzaż Nowego Jorku, po którym przechadza się bohater wierszy Reznikoffa, zaludniają więc ludzie więcej niż zwykli: to często zmęczeni robotnicy, drobni sklepikarze, rzemieślnicy i ich rodziny, zajmujący się zwykłymi, codziennymi czynnościami, prowadzący małe interesy lub po prostu żebracy, klepiący biedę. Są oni przy tym przedstawicielami wielu różnych nacji: to zarówno Żydzi, jak i Afroamerykanie, ale też Irlandczycy, Włosi, Węgrzy oraz Portorykańczycy.

Przewrażliwienie i paranoja - pisze Fredman - które mogą być tego rezultatem [zinternalizowania rasowych stereotypów - J.O.] zostają przetransponowane w produktywne wartości, takie jak szczególna wrażliwość wobec wszelkiego rodzaju wykluczających praktyk, rygorystyczna dyscyplina, jeśli chodzi o autoanalizę i subtelna tendencja demitologizacyjna (MFA, 21).

Istnieje wiele przyczyn, dla których poezja Reznikoffa mogła okazać się dla Piotra Sommera istotną lekturą. Wybory tłumacza-poety, zwłaszcza tak ściśle określone jak w przypadku autora antologii O krok od nich, nazwanego przez Jerzego Jarniewicza legislatorem obcych języków ${ }^{13}$, dużo mówią o jego pasjach artystycznych. W szkicach zamieszczonych w Po stykach czy w Artykułach pochodzenia zagranicznego wartość wybranych przez niego, szczególnych poetyk jest dodatkowo wzmacniana, uzasadniana krytycznie, a punkt ciężkości argumentów sprowadza się zazwyczaj do kilku estetyczno-etycznych tez i wniosków, stanowiących dla Sommera specyficzne sine qua non. Ci najważniejsi dla niego bohaterowie - amerykańscy, jak Reznikoff, John Berryman, Frank O’Hara, John Ashbery czy też pochodzący z Wysp poeci rozmaicie rozumianych marginesów brytyjskości, jak Brian Patten, Douglas Dunn czy Michael Longley - to twórcy, których wyróżnia predylekcja do zdania bliskiego zwykłej mowie, jej rytmowi i melodycznej frazie, najlepiej odnajdującej się w wierszu wolnym (choć niekoniecznie); zdania przy tym niezbyt zmetaforyzowanego, któremu towarzyszy specyficzny stosunek autorów do poezji - wstępnie określić można by go antymetafizycznym. Poezja tych twórców nie odsyła bowiem - całkowicie

\footnotetext{
${ }^{12}$ R. Omer-Sherman, Diaspora and Zionism in Jewish American Literature. Lazarus, Syrkin, Reznikoff, and Roth, Brandeis University Press, Hanover and London 2002, s. 114 i n. Dalej oznaczam w tekście jako DAZ. Tłumaczenia z tego źródła J.O.

${ }^{13}$ Jarniewicz w tekście Tlumacz jako twórca kanonu proponuje, by uwzględnić odmienną postawę tłumaczy-ambasadorów, którzy próbują tłumaczyć „całość” kanonu literatury angielskiej, jak Barańczak czy Słomczyński i tłumaczy-legislatorów, jak Sommer czy Zadura, którzy nie przykładają się do konstytuowania kanonu w zgodzie z obecnymi już wewnątrz niego ideami tak czy inaczej pojętej całości. Badacz pisze, iż tłumacze-ambasadorzy raczej „tworzą kanon na własne potrzeby", pracując poniekąd przy tym nad kondycją współczesnego polskiego języka literackiego, poprzez własne legislacje „obcości” próbując na niego wpłynąć (J. Jarniewicz, Tłumacz jako twórca kanonu, w: tegoż, Gościnność stowa. Szkice o przekładzie literackim, Znak, Kraków 2012).
} 
w sprzeczności z modernistyczną tendencją zapoczątkowaną przez wariant imażynizmu związany z poezją Eliota - do znaczeń, których umocowanie miałoby miejsce w „niewyrażalnym”, a co nie znajdowałoby miejsca w samym poetyckim języku. Za antymetafizyczną postawą idzie pewność co do siły wyrazu i piękna awangardowego języka oraz cechująca wiersz (poza ścisłym odniesieniem do historycznoliterackiego, amerykańskiego terminu) specyficzna obiektywność. Tekst stanowi twór poniekąd emblematyczny: dosłowny i nieprzezierny w swoich znaczeniach, przeczy więc zasadzie alegorii (może się odnosić do niej z rzadka, na ironicznej zasadzie). Poeta traktuje także rozmaite (językowe i niejęzykowe) doświadczenia jako swego rodzaju twórczą materię, wskazując jednak w punkcie dojścia zawsze na sam wiersz - jako na artystyczny przedmiot. Tak pomyślany tekst poetycki jest - jednym słowem - do krwi świecki; dopuszcza modyfikacje, choć ze względu na swą precyzyjną konstrukcję, podobnie jak tekst święty, nie znosi zmian. Praktyka poetycka, która interesuje Sommera jako thumacza-rzemieślnika przede wszystkim, związana byłaby z awangardowymi impulsami modernistycznych literatur, zwłaszcza kiedy przechylają się one już w stronę tendencji postmodernistycznych.

Polski Reznikoff Sommera różni się przy tym znacząco od Reznikoffa amerykańskiego, bohatera książek Stephena Fredmana czy Ranena Omer-Shermana, którzy zasadniczym tematem swoich rozważań czynią ambiwalentną postawę amerykańskiego awangardzisty o żydowskich korzeniach - opisywaną zarówno wobec rozkwitającej w Stanach w latach trzydziestych idei syjonizmu, jak i wobec odziedziczonych po europejskich przodkach tradycji diasporycznych. Reznikoffowski kanon w wyborze Sommera, zarówno tym z początku lat dziewięćdziesiątych, znanych z Graffiti, jak i z późniejszych antologii: Artykułów pochodzenia zagranicznego (1996) i O krok od nich (2006), uległ w ciągu kilkunastu lat pewnym przesunięciom, ale nie znaczącemu poszerzeniu. Wiele wierszy z Graffiti nie weszło do późniejszych wyborów (aż 31); w tychże z kolei pojawiło się trochę tłumaczeń wierszy wcześniej nie uwzględnionych (12 tekstów). Przy tym do ostatniego wyboru poezji amerykańskiej włączono jedynie osiem nowych utworów (znajduje się w nim w sumie około 50 wierszy Reznikoffa). Wiersze nowe, dodane do podstawowej grupy tłumaczeń z Graffiti, poruszają przy tym często tematy żydowskie - widać więc, że tłumacz próbował wyrównać pewne niedoreprezentowanie tego ważnego dla Reznikoffa tematu w pierwszym wyborze. Wiele z przetłumaczonych na polski tekstów to charakterystyczne dla amerykańskiego poety miniatury, które w zbiorach Reznikoffa funkcjonują jednak inaczej niż w wyborach Sommera. Autor Jerusalem the Golden umieszczał je w swoich wczesnych tomach, numerując poszczególne wiersze po arabsku, niektóre z nich dodatkowo tytułując; w późniejszych książkach zaś grupował je jeszcze w cykle, niektóre wyróżnione numerami rzymskimi, czasem także nadając tytuł całości 
cyklu ${ }^{14}$. Przywodzi to wszystko na myśl tradycję epigraficzną; Ranen Omer-Sherman odprowadza teksty Reznikoffa do homiletycznych gatunków żydowskich, takich jak midrasz czy przypowieść (można tu dodać jeszcze misznę) - często zresztą traktowanych w Reznikoffowskiej interpretacji ironicznie (DAZ, 170). Całym garściom miniatur towarzyszą jednak zwykle dłuższe wiersze - tematycznie podtrzymujące charakter miniatur, albo przeciwnie - wskazujące na inne teksty autora, wydawane w podobnym czasie, takie jak sztuki historyczne, pisane w tradycji diasporycznej czy też opowiadania o charakterze autobiograficznym, obyczajowym. Cykle osobnych miniatur często są także puentowane utworami długimi, przypominającymi poematy. Tak na przykład wygląda Separate Way z 1936 roku; miniatury przechodzą tu w wiersze o charakterze historyczno-obyczajowym, zatytułowane kolejno Depression, Messianic, The Socialists of Vienna. Potem następuje poemat New Nation, przedstawiający przybycie do Ameryki pierwszych osadników angielskich, a w końcu długi wiersz Palestine under Romans, oparty na angielskim tłumaczeniu tradycyjnej miszny. Czasem dłuższe teksty wprowadzają na początku tematy duże, religijne, historyczne, a później ich sensy są poniekąd rozpraszane, niuansowane przez ciągi obyczajowych miniatur. I tak Going to and Fro and Walking Up and Down rozpoczyna A Short History of Israel. Notes and Glosses. Wybrane z tego tomu przez Sommera miniatury pochodzą z wieńczących tom cyklów Autobiography: New York i Autobiography: Hollywood. Całość projektu poetyckiego Reznikoffa sprawia wrażenie ciągłości: jakby autor pisał jeden utwór wielotematyczny, zawsze mający w swoim centrum pewną określoną problematykę, przez Shermana określaną jako diasporyczną - problematykę zachwianej tożsamości i wygnania, przejawiającą się poprzez rozmaite gatunki, tworzące jednak przemyślaną, autobiograficzną w swoim charakterze i otwartą w końcu całość. Wątki żydowskie najczęściej przy tym wiążą się z najpowszechniej rozpoznawalnymi punktami zwrotnymi religijnej historii. Ofiara z Izaaka, niewola egipska i wyjście z Egiptu, zburzenie Świątyni i niewola babilońska - aż do ustanowienia nowoczesnego państwa Izrael: wszystko to szeregi wydarzeń, dla których znaczący jest element cierpienia wygnanych i ich zaufania w sens boskich wyroków pomimo wszystko - w samym środku matni prześladowań, bezdomności i obcości. Takie etyczno-wyznaniowe wzorce, towarzyszące im wydarzeniowe schematy zaczerpnięte z pism świętych, przenoszone są przez Reznikoffa w nowoczesną, amerykańską angielszczyznę i we współczesne historyczne realia; w końcu odnoszone są - dyskretnie i subtelnie, z pew-

\footnotetext{
${ }^{14}$ Kiedy amerykański poeta przygotowywał swój pierwszy wybór By the Waters of Manhattan dla wydawnictwa New Directions, w stosunku do swoich wczesnych wierszy przyjął opisany powyżej model zapisu, pierwszy raz zastosowany w tomie Jerusalem the Golden, wydanym w 1934 roku. Tropem autorskiej decyzji poszedł Seamus Cooney, redaktor wyboru z 2005 roku, z którego tutaj korzystam: The Poems of Charles Reznikoff 1918-1975, red. S. Cooney, Black Sparrow Books, Boston 2005. Cytaty z tego źródła dalej oznaczam jako PChR.
} 
nego rodzaju sceptycyzmem poznawczym cechującym kogoś w gruncie rzeczy nieortodoksyjnego, choć dotrzymującego wiary diasporycznej tradycji przodków - do historii własnego życia i historii życia własnej rodziny, nieodłącznej od tej dużej, historii żydowskiego wygnania. Dla jej charakteru - właśnie w związku z żydowską tradycją - dodatkowo niezwykle znaczące jest to, że jest ona tekstualna. Diasporyzm początek swojej historii wywodzi od wygnania Żydów z Babilonu (587 r. p.n.e.), kiedy utraconą Świątynię zastąpiła Tora, a składanie drogich, materialnych ofiar - studiowanie jej i modlitwa, czemu towarzyszyła również wzrastająca świadomość wagi języka. Jak pisze Omer-Sherman:

Kiedy nadzieje na suwerenność i zamieszkiwanie we własnym domu okazywały się mrzonkami, ciągłe przebywanie na wygnaniu, bez praw obywatelskich, otworzyło całą wielką przestrzeń dla liturgicznej i literackiej wyobraźni Żydów. Nadal przemawia ona w sprawie przerażającej różnorodności globalnych wypędzeń i przymusowych przesiedleń, które tragicznie ustanowiły podłoże dla naszej nowoczesności i ponowoczesności (DAZ, 5).

W swoich wyborach Sommer wyłącza miniatury Reznikoffa z cyklów, w których stanowią one jedynie część opowieści współtworzonej przez rozmaite formuły Reznikoffowskiego wiersza. Daje im także oprawę należną poetyckim majstersztykom - w postaci osobnej strony dla każdego utworu. Nie jest to zgodne z intencją rozmywającego granice poszczególnych utworów oryginału. W polskiej prezentacji mniej jest zdecydowanie tekstów dłuższych o narracyjnym charakterze, zupełnie zaś brak długich poematów religijno-historycznych, stanowiących przedłużenie tego, co robił amerykański autor w latach dwudziestych, wydając swoje Nine plays. Uderza zaś przede wszystkim niewielka obecność wierszy ,żydowskich” wśród tłumaczeń Sommera - od krótkich, bardzo słynnych i często przytaczanych przez badaczy tekstów, takich jak „How difficult for me is Hebrew:/ even the Hebrew for mother, for bread, for sun/ is foreign. How far have I been exiled, Zion" (Fifth Group of Verse, P, 58) ${ }^{15}$, po ważne, nawiązujące do treści sztuk długie utwory, jak np. Jerusalem the Golden, tekst kończący tom pod takim właśnie tytułem (lektura incipitów jego czterech części może dawać pewne wyobrażenie o treści, to kolejno: Lion of Judah, The Shield of David, Spinoza, Karl Marx). Brak zarówno reorganizujących treść całych tomów poematów - takich jak In Memoriam: 1933 (1934), podążającego historycznym śladem żydowskich nieszczęść od tekstu Samaria Fallen: 722.B.C.E. po Russia: Anno 1905, jak i narracji autobiograficznych - poematu By the Well of Living and Seeing (1969), zatytułowanego Early History of the Writer, pokazującego życie żydowskich emigrantów w Nowym Jorku z okresu dzieciństwa poety, z początku

${ }^{15}$ Wiersz obecny w Graffiti, niezamieszczony w późniejszych wyborach Sommera. 
XX wieku. Poezja Reznikoffa funkcjonuje w języku angielskim, w kompletnym wydaniu Seamusa Cooneya, jako swego rodzaju wielka, płynąca, posiadająca historyczno-autobiograficzny charakter całość - obiektywistyczna między innymi w takim sensie, że bardzo mocno dokumentalistyczna, koncentrująca się na fakcie - rozumianym w kategoriach historycznych źródeł albo prawniczych precedensów. W zbiorze Cooneya w niewielkim stopniu uwzględniono tylko (i podobnie postępuje Sommer) najsłynniejsze chyba dzieło Reznikoffa - jego Testimonies: dwa tomy „,recytatywów”, nad którymi autor pracował ponad czterdzieści lat, a które zaczęły powstawać, kiedy - jako świeżo upieczony prawnik - przygotowywał hasła do Corpus Juris, encyklopedii prawa do użytku sądowego. Teksty te stanowią poetyckie transpozycje zeznań świadków zbrodni, wyciągniętych z amerykańskich zbiorów orzecznictwa sądowego; właśnie one zadecydowały w tym, w jaki sposób sam autor rozumiał pojęcie 'obiektywizmu'16. Z całości ogromnego poetyckiego dzieła Reznikoffa trudno cokolwiek wyłączyć; sam wybór spośród tych wierszy wydaje się znaczący i może być swoistym wyzwaniem dla thumacza. Melodie poetyckich miniatur rozsupłujące się w narracje o zdaniach napisanych właściwie oszczędną prozą; etyczna postawa świadka, która decyduje o kształcie narracyjnych przedstawień; przesiąknięte etyczną dyrektywą wybory poetyckich tematów - skupiających się na rzeczach zwykłych, małych, na ludziach niepozornych, biednych, obcojęzycznych, zapełniających szeroko pojęte marginesy nowojorskiej kultury - dopiero to wszystko tworzy całego Reznikoffa. Jego żydowskie wiersze to fascynujący przykład narracji bliskiej stylowi historyczno-biograficznemu, pozbawionemu właściwie typowej dla awangardy gęstości znaczeń. Tożsamość poetów-obiektywistów (Zukofsky’ego, Oppena, Reznikoffa, Rakosiego) to sprawa decydująca dla rozumienia wielu cech ich twórczej strategii. Młodzi żydowsko-amerykańscy pisarze, przedstawiciele nowojorskiej bohemy, w swoich domach byli wychowywani w tradycyjny sposób, a czasem nawet, tak jak Zukofsky, mówili tam w jidisz. Później, z własnego wyboru, asymilowali się z nowoczesną kulturą Stanów Zjednoczonych: kończyli

\footnotetext{
${ }^{16}$ Reznikoff, pisząc swoje Testimonies, przerzucił wiele tomów akt prawnych, gromadzących dokumenty orzecznictwa sądowego. Sam mówił, że nie wie, ile tysięcy ich przerzucił, żeby wyciągnąć z nich swoje ,recytatywy”. W rozmowie z Lawrencem Sanfordem Dembo Reznikoff powiedział, że Testimony jako gatunek, ,świadectwa” można wyjaśnić podążając za Eliotowską definicją „korelatu obiektywnego”, tak jak sam ją rozumiał: „Coś się dzieje i właśnie to wyraża coś, co czujesz, niekoniecznie ze względu na te właśnie [przedstawione - J.O.] fakty, ale ze względu na zupełnie inne fakty, które dają ci dokładnie taki sam rodzaj uczucia. I teraz, kiedy czytasz akty prawne, jeżeli natykasz się na sprawy ustalające pewne fakty, często odbywa się to w jednym zdaniu lub dwóch; ale czasami zobaczysz, że fakty zostają pogłębione, przechodzą w detal, czasami po to, by wyjaśnić albo obronić konkretne sędziowskie orzeczenie. [...] W Testimony świadkowie, których słów użyłem, wszyscy w taki sposób składają zeznania dotyczące czegoś, co rzeczywiście przeżyli” (L. S. Dembo, An Interview with Charles Reznikoff, „Contemporary Literature” 1969, nr 10, s. 202; podaję za źródłem http://www.jstor.org/stable/1207760 [dostęp: 10.11.2014]).
} 
nowoczesne, amerykańskie uniwersytety i pisali w języku angielskim. Poczucie pewnej chwiejności, ambiwalencji, związane z ich rezydowaniem na pograniczu dwóch kultur, zyskuje wyraz w poetyce, która potrafi rejestrować napięcia obecne w miejskim, multietnicznym organizmie. Według Stephena Fredmana młodzi obiektywiści, przynależący do awangardowego zwrotu w kulturze, przetransformowali „czystość” właściwą dla tekstów żydowskiej religii (z koniecznością strukturalnej precyzji, gęstością i zwięzłością właściwą dla hebrajskiego języka, przejrzystością homiletycznych epigrafów) - w „czystość” konstruktywizmu i gęstości znaczeń właściwych dla awangardowej praktyki (MFA, 28) ${ }^{17}$. Ta szczególna sytuacja żydowskich poetów czasów awangardy wydaje się powiązana z obowiązkiem „tłumaczenia” przyrodzonym twórcom, którzy w żadnym języku nie czują się jak w domu. Utracili wszak swój hebrajski, a swoje nowe miejsce muszą wypracowywać w obcym, amerykańskim idiomie, z którym identyfikują się wprawdzie jak z własnym, ale który pozostaje jednocześnie dla nich często wykluczającym żywiołem. To miejsce ironicznie zostało im ofiarowane przez awangardę związaną z imażynistycznymi ideami Ezry Pounda ${ }^{18}$.

$\mathrm{Z}$ drugiej strony niewielka obecność wierszy żydowskich w wyborze Sommera nie budzi zdziwienia. Swoista dla Reznikoffa sygnatura obcości jest czymś, co stanowi decydujący element nawet najdrobniejszych utworów. Miasto w jego wierszach obserwowane jest zdystansowanym okiem, nie tylko ze względu na „pograniczną” tożsamość autora. Rachel Blau DuPlessis i Peter Quartermain we wstępie do antologii tekstów poświęconych obiektywistom komentują manifest Zukofsky'ego, który, wybierając na patrona dziesięć lat od siebie starszego, żydowskiego poetę, stawiając go ponad przywoływanymi także Williamsem i Poundem, zdecydował się na włączenie awangardowego obiektywizmu w tradycję nieuznawaną i archaiczną - żydowską, powiązaną z językiem jidisz ${ }^{19}$. Społeczny

${ }^{17}$ Jak pisał Fredman, żydowscy pisarze piszący w obcych dla siebie, europejskich językach - tacy jak Franz Kafka, Bruno Schulz czy Gertrude Stein - wykorzystali twórczo marginalną pozycję zajmowaną przez siebie w społeczeństwie, by wykreować wpływowe modele modernistycznej praktyki: „Pierwszym doświadczeniem XX wieku było czasami szokujące doświadczenie, że każdy z nas jest cudzoziemcem; że społeczeństwa nie funkcjonują dłużej jako zrozumiałe same przez się [narodowe - J.O.] całości. Żydowscy pisarze nie tylko przyłożyli się do tworzenia modelu nowoczesności poprzez rozmaite językowe eksperymenty, ale i pisali teksty dające z pełną precyzją wyraz tej szczególnej, nowej kondycji człowieka: bycia w zachodniej kulturze zarazem w domu i obcym" (MFA, 100).

${ }^{18}$ Poundowi bardzo podobały się utwory Reznikoffa, które Zukofsky wysłał mu do Rapallo we Włoszech. Napisał w liście powrotnym, że następna fala awangardowej poezji, którą sam zaprojektował, będzie żydowska. Fredman nazywa korespondencję Zukofskiego z Poundem - żydowskiego poety z antysemickim mentorem - jako „przedziwną, o wodewilowym charakterze” (MFA, 130).

${ }^{19}$ Zwracają na to uwagę we wstępie do zbioru szkiców The Objectivist Nexus DuPlessis i Quartermain. Od 1890 roku do lat trzydziestych w Stanach rozkwitała twórczość w nowoczesnej odmianie tego germańskiego języka diaspory, zapisywanego w hebrajskim alfabecie: głównie ludowa, 
kontekst obiektywistycznych wierszy i etyczny aspekt związany z tradycją, która internalizuje cierpienie wygnania jako źródło sensu żydowskiej religii, w przypadku Reznikoffowskich miniatur może stanowić drugi, ale nieodłączny plan - podczas gdy w długich wierszach okazuje się zasadniczym przedmiotem uwagi autora $^{20}$. Trudno byłoby chyba przyswoić polszczyźnie długie wiersze Reznikoffa tak, by skupić uwagę czytelnika na tym, co jest w nich najbardziej atrakcyjne - związane ze zdaniem jego poetyckiego języka. W tym przypadku mamy do czynienia ze składnią angielską, o wiele bardziej giętką i plastyczną, jeżeli chodzi o formułowanie znaczeń tekstu niż składnia języków słowiańskich, w których sufiksy unieruchamiają czasowniki. Możliwe, że długie poematy autora $B y$ the Well of Living and Seeing, zwłaszcza autobiograficzne, rozpadłyby się po polsku po prostu w prozę. W krótkich tekstach zaś o wiele łatwiej jest uchwycić istotę wielkiego talentu Reznikoffa. Tłumaczenia Sommera są nie tylko doskonałe - niosą w sobie także element osobistego doświadczenia twórczego, związanego z przyswajaniem „obcego” języka poezji językowi własnemu - nie tyle polskiemu, ile własnemu językowi poezji. Być może wiersze żydowskie, często zaopatrzone dociskającym znaczenia etycznym akcentem lub wyrazistą puentą, wydawałyby się tłumaczowi zbyt oczywiste po polsku w porównaniu z gnomicznością i nieprzejrzystością obiektywistycznych detali czy emblematyczną, niealegoryczną scenerią wielokroć przedstawianej nowojorskiej ulicy... Być może zanadto zanurzone były w lokalnym kontekście, który wydawał się Sommerowi nie do przeniesienia? Może też Sommer nie chciał talentu Reznikoffa osłabiać, przedstawiając go w aż nadto dzisiaj wyrazistym i atrakcyjnym kulturowo-politycznym kontekście kultury jidisz, który odwracałby uwagę od - niełatwej do oddania w polszczyźnie - językowej maestrii poety? ${ }^{21}$ Tak czy owak, to, co Som-

satyryczna, często socjalistyczna, anarchistyczna o proletariackich korzeniach. W 1920 roku grupa, która określiła się mianem introspektywistów, wydała manifest zatytułowany In Zich - z programem bardzo przypominającym obiektywistyczny (pragnęli zwracać się ku zwykłemu życiu, z poetycką precyzją); liczne analogie dotyczyły także samych wierszy (ze względu na społeczne zaangażowanie, troskę o wykluczonych, motywy, takie jak ciągła wewnętrzna ,introspekcyjna” debata ze sobą, czy też intymne, pełne emocji, choć i szorstkie „spieranie się z Bogiem” (R. Blau DuPlessis and Peter Quartermain, Introduction, w: The Objectivist Nexus. Essays in Cultural Poetics, red. R. Blau DuPlessis, P. Qartermain, University of Alabama Press, Tuscaloosa and London 1999, s. 15. Tłumaczenia z tego źródła J.O.).

${ }^{20}$ Autorzy Wstępu do książki The Objectivist Nexus mówią wprost, że wieloletnia marginalizacja żydowsko-amerykańskich poetów awangardowych, biorąc pod uwagę liczbę poetów żydowskich w szeregach obiektywistów (wszyscy poza Basilem Bautingiem i Lorine Niedecker), mogła być powiązana $\mathrm{z}$ (podświadomym nawet) antysemityzmem, jak to było w przypadku kariery takiego pisarza jak Lionel Trilling.

${ }^{21}$ Pewnym kluczem dla zrozumienia takich, a nie innych decyzji tłumacza może być fragment cytowanej już rozmowy, przeprowadzonej dla „Kwartalnika Artystycznego”. Na pytanie Barbary Łopieńskiej o wybór Kolejowe dzieci, dotyczący nieobecności najbardziej znanych wierszy Heaneya, związanych z trudną historią Irlandii, Sommer odpowiada: „To mówisz, że historia Irlandii 
mer przetłumaczył, idzie raczej tropem sformalizowanej myśli awangardowej lat trzydziestych - co jako sposób lektury obiektywistów pozostaje także wynikiem pewnej tradycji, wiążącej się z wypowiedziami modernistycznie zorientowanych krytyków, takich jak Hugh Kenner, Marjorie Perloff czy Peter Nicholls. W swoich analizach roztrząsają oni raczej formalne kwestie, dostrzegając w wierszach kontynuację koncepcji imażynistycznych. Charles Altieri na przykład w szkicu The Objectivist Tradition wskazuje jako ich źródło poezję Safony, pisarstwo Flauberta i koany Zen, nie licząc przywoływanych przy okazji Eliota i Pounda czy w końcu Williamsa. Altieri pisze o tym, że poezja obiektywistyczna to przede wszystkim wola dyscypliny i krytyczny stosunek do profetycznej roli poezji jako zasadniczej przesłanki twórców XIX-wiecznych: „Obiektywizm to nie tylko uwaga poświęcana przedmiotom: zakłada konstrukcję przedmiotu estetycznego w taki sposób, że kontekst [twórczego - J.O.] pragnienia zostaje zdramatyzowany; ponosi odpowiedzialność za twórcze poczynania"22. Według krytyka to konstrukcja, więc funkcja, nie opis, stanowi model dla obiektywistycznej referencji, czego źródła można odnaleźć także w kolażowych technikach awangardy (to zwłaszcza w odniesieniu do poezji George’a Oppena). Rozgrywające cechy obiektywizmu to według Altieriego antyromantyczny i antysymboliczny impuls, co umieszcza obiektywistyczną rewolucję w poezji w ramach szerszej tradycji imażynizmu, którego miejsce $\mathrm{w}$ historii literatury - w charakterze początków anglosaskiego modernizmu - wyznaczył (głównie za przyczyną Eliota) zwrot przeciwko subiektywizmowi epigonów romantyzmu. Nie znaczy to, że, tak zdekontekstualizowana, odnajdująca się w autotelicznym opisie procesu literackiego tendencja stanowi przesłankę wyborów Sommera. Wydaje się, że polski tłumacz nie chce rezygnować z impulsu etycznego czy z elementów etnicznych kształtujących całość poezji Reznikoffa - polski Reznikoffowski kanon zostaje znacznie odchudzony - ale nie zubożony.

była burzliwa? [...] W kontekście irlandzkim i polskim ważne te same frazy w tych samych wierszach u tych samych poetów? To by z kolei znaczyło, że ktoś taki jak Ficowski albo Miłobędzka ma szansę w kontekście irlandzkim być tak samo ważny, jak jest ważny, albo jak może być ważny dla mnie albo dla ciebie po polsku. Nie ma takiej możliwości. Moim zdaniem «wiersze ważne w kontekście lokalnym» mogą być z góry ważne w kontekście innokulturowym tylko wtedy, kiedy przyjmiemy, że skoro te wiersze są ważne gdzie indziej, w jakimś odmiennym politycznym czy historycznym kontekście, to i po naszemu «będą ważne, bo mają ważne być, spocznij». [...] A ja uważam, że coś może być znaczące «u nas», dopiero wtedy, kiedy okaże się znaczące po polsku, wcześniej nie. Bo o ważności w przekładzie decyduje najczęściej nie to, co decyduje o ważności w oryginale" (KA, 56).

${ }^{22}$ Ch. Altieri, The Objectvist Tradition, w: The Objectivist Nexus, s. 30. Altieri odnosi się tu do fragmentu wypowiedzi Zukofsky'ego Prepositions, w której ten - w swoim dziwnym stylu - ucieka się do personifikacji aktu twórczego, który dyscyplinę ,,poetyckiej woli” określa niemal w kategoriach uwolnionej siły o niesprecyzowanym źródle, a sam wiersz traktuje niczym żywy organizm, ulegający tu niemal aktom twórczej przemocy; stąd możliwy jest apel wzbraniający „,narzucania woli w wierszu bez odpowiedzialności za jego akty” (tamże). 
Zukofsky w najbardziej znanym fragmencie manifestu opisuje „obiektywizm” ('objectification') i powiązaną z nim ,szczerość” ('sincerity') w następujący sposób:

W szczerości [tekstu - J.O.] kształty towarzyszą kombinacjom słów, zapowiadając (jeżeli następuje kontynuacja) całkowitość dźwięku czy struktury, melodii czy formy. Powstaje taki styl pisania, który cały jest w detalu, nie w wyobrażeniu - tego, co się widzi, o czym się myśli, podążając za rzeczami tak, jak istnieją, poddając je liniom melodii. Kształty stają się sugestywne, a umysł wyczuwa i uczy się uważności. Gdybyśmy szukali paraleli w innej sztuce, byłaby to perfekcyjna linia przypadkowego rysunku lub wyrazisty początek rzeźby, która nie została skończona. Wobec szczerości sam umysł wytwarza - jako dalszą sugestię, która nie przemieni się w uspokojoną całość - tę całość właśnie, którą sama szczerość nie zawsze przyniesie, a która konieczna jest jedynie w charakterze perfekcyjnego wykończenia, i dla całkowitego uznania. Taka wykończona całość mogłaby być określona „obiektywnością” - jako oczekiwanie całkowicie spełnione, jeżeli chodzi o sztukę, która przybrałaby formę obiektu ${ }^{23}$.

Obiektywizm Reznikoffa, rozwijający, czy też raczej doprecyzowujący rozmaite wątki i myśli obiektywistycznego manifestu w autokomentarzu do własnego poetyckiego warsztatu, Obiter Dicta (termin prawny oznaczający niewiążącą opinię sędziego w danej sprawie), samym tytułem sugeruje inne, zdecydowanie mniej modernistyczne w tonie nachylenie koncepcji poetyki. Najważniejsze dla Reznikoffa są faktycznie kwestie techniczne, jako źródła swojej metody wskazuje: anglosaski awangardowy wiersz wolny (Pounda, Hildy Doolittle), francuski wiersz wolny, nieregularne rytmy wiersza Whitmanowskiego - z drugiej strony przekład Biblii Króla Jakuba i podobnie nieregularne rytmy poezji anglo-saksońskiej:

[...] kiedy pierwszy raz zetknąłem się [z takim wierszem - J.O.] wydawał mi się całkowicie w porządku: bez docinania do wzorów, jakkolwiek mistrzowskich, ani wciskania w gotowe formy, tylko słowa i frazy płynące jak myśl; do czytania jak

${ }^{23}$ „In sincerity shapes appear concomitants of word combinations, precursors of (if there is a continuance) completed sound or structure, melody or form. Writing occurs which is in detail, not mirage, of seeing, of thinking with the things as they exist, and of directing them along a line of melody. Shapes suggest themselves, and the mind senses and receives awareness. Parallels sought for in the other arts call up the perfect line of occasional drawing, the clear beginnings of sculpture not proceeded with. Presented with sincerity, the mind tends to supply, in further suggestion which does not attain rested totality, the totality not always found in sincerity and necessary only for perfect rest, complete appreciation. This rested totality may be called objectification - the apprehension satisfied completly as to the appearance of the art form as object" (Louis Zukofsky, dz. cyt., s. 273; tłum. J.O.). 
by to była zwykła mowa, oprócz konieczności przystanięcia na końcu każdej linijki - a to jakby przy oddechu w muzyce, albo zwrocie w tańcu. (Nie traktowałbym tego jak krytyki, gdyby ktoś powiedział, że przy czytaniu takiego wiersza jak prozy, on po prostu staje się prozą, bo nie został napisany do tego, by go czytać, jak został napisany $)^{24}$.

Samo pojęcie obiektywizmu doprecyzowuje jednak dla siebie dopiero w odniesieniu do materii wiersza:

Przez pojęcie „obiektywista”, jak sądzę, moglibyśmy rozumieć takiego pisarza, który nie pisze wprost o swoich uczuciach, ale o tym, co widzi i słyszy; który ogranicza się niemal do wymiaru zeznania świadka w sprawie sądowej; który wyraża swoje uczucia pośrednio, poprzez selekcję materiału, $\mathrm{i}$ - jeśli pisze wiersz - poprzez jego melodię 25 .

Odniesienia do gatunku świadectwa - zeznania sądowego, jego „obiektywizmu", związanego ze specyfiką prawniczego języka i samego prawa jako (jednak) swoistego przedmiotu raczej niż tekstu - pojawiają się w wypowiedziach poety w wielu miejscach. Zdystansowanemu oglądowi świadka towarzyszy zawsze domyślna intensywność emocji, sprowadzonej do nieobecnego kontekstu; uzyskuje ona dyskretne przełożenie na autorską organizację materiału. Swoiste zasady, którymi poeta chce się kierować, jeżeli chodzi o technikę, to „czystość”, precyzja, porządek - z których wynika jednak właśnie swego rodzaju ,intensywność”. Przynosi ją zwięzłość, rytm, czasem rym lub aliteracja: „Słowo z prozy staje się wierszem, kiedy mowa napełnia się pasją i staje się muzyczna zamiast płaska" ${ }^{26}$.

Paradoksalnie pragnienie przezroczystości własnego ,ja” w tłumaczeniu - o którym pisze Sommer na wstępie do szkicu o Reznikoffie zamieszczonym w Artykułach pochodzenia zagranicznego, a przedrukowanym w Po stykach ${ }^{27}$

${ }^{24}$, ,[...] seemed to me when I first read it just right: no cut to patterns, however cleverly, nor put into ready moulds, but words and phrases flowing as the thought; to be red just like a common speech but for stopping at the end of each line - and this like a rest in music or a turn in the dance. (I found it no criticism that to read such verse as prose was to have a kind of prose, for it was not to read it as it was written.)" (PChR, 371; tłum. J.O.).

25 „By the term «objectivist», I suppose a writer might be meant who does not write directly about his feelings but about what he sees and hears; who is restricted almost to the testimony of witness in a court of law; and who expresses his feelings indirectly by the sellection of his subject matter and, if he writes in verse, by its music" (tamże).

${ }^{26}$,The word move out of prose into verse as the speech becomes passionate and musical instead of flat" (PChR, 373).

${ }^{27}$ Sommer pisze: „Rola tłumacza [...] to rola możliwie jak najbardziej sprawnego i rzetelnego od-twórcy, który w swojej pracy powinien się kierować wyłącznie «wizją» (czyli literą i duchem) oryginału. Cała reszta, [...] te wszelkie formy objaśniania w obrębie tłumaczonego tekstu - ukryte glosy, redukowanie oryginału bądź jego nawiedzone przetwarzanie - będzie uzurpacją, wyjściem 
- mogłoby odpowiadać zasadzie twórczej, którą w swoim obiektywizmie wyznaje amerykański autor. Cytując w Obiter Dicta wypowiedź z francuskiej ulotki traktującej o Zen, Reznikoff mówi o bardzo ważnej dla siebie sprawie - przezroczystości tego, co subiektywne - tak, żeby emocje towarzyszące aktowi twórczemu w samym dziele były wyrażone jedynie jako ślad, w selekcji przedmiotów opisu i w muzyce zdania: „«Bo Zen, w poszukiwaniu oświecenia, to znaczy bezpośredniego kontaktu z wszechświatem... największy nacisk kładzie na osobisty wysiłek i zapomnienie siebie»»" (PChR, 372; podkr. moje). Przy każdej okazji właściwie, przy każdej rozmowie, każdym spotkaniu autorskim, Sommer pytany o Reznikoffa, przypomina wiersz przełożony przez siebie już dawno, opublikowany po polsku w roku $1980^{28}$, pochodzący zaś z tomu Jerusalem the Golden: „What are you doing in our street among the automobiles,/ horse?/ How are your cousins, the centaur and the unicorn?" (PChR, 101). Daje tym samym świadectwo wielkiego wrażenia, jakie ten tekst na nim wywarł, nazywając go ,jednym z najdoskonalszych wierszy Reznikoffa", stanowiącym syntezę całej filozofii poetyckiej amerykańskiego twórcy:

[...] wraz z rolą, która przyznana zostaje muzyce, czyli intonacji, pojedynczego zdania (refreniczności pytań w tym przypadku); z wyrazistym acz nie wybitnym efektem retardującej, by tak powiedzieć, składni perypatetyka; wreszcie - ów charakterystycznie niedopowiedziany punkt obserwacyjny przechadzającego się po mieście ,ja”, nieustająco u Reznikoffa ważny. Informacji o podmiocie lirycznym dostarcza, rzecz jasna, również słownictwo (PS, 222).

Obiektywistyczne wiersze Reznikoffa są więc nieosobiste, a podstawowy ich materiał wynika z obserwacji, którą w pewnym stopniu można by nazwać bezstronną, choć nie jest ona pozbawiona emocji. Właściwa dla takiego charakteru „obserwacji” pozostaje poniekąd podwójna strategia podmiotu, który ujawnia się najczęściej - zwłaszcza w miniaturach - poprzez element zadziwienia tym, co stanowi materiał doświadczenia, przekładającego się na poczucie „obcości” i na pewne emocjonalne przejęcie się tym, co obserwowane, a co pozostaje - w sferze wyrazu, semantyki - nieuwzględnianą w wierszu resztą, możliwą do wydedukowania z napięć, które poetyckie uporządkowanie materiału właśnie wydaje się sugerować. Większość miniatur ze zbiorów, z których pochodzą tłumaczenia Sommera (Poems, Jerusalem the Golden, Going to and Fro) skonstruowana zostaje na

z roli, arogancją parafrazy" (P. Sommer, Ttumaczac miniatury Charlesa Reznikoffa, w: tegoż, Po stykach, Słowo/Obraz Terytoria, Gdańsk 2005, s. 220; przedr. za antologią poezji amerykańskiej w tłumaczeniu Sommera Artykuły pochodzenia zagranicznego). Cytaty w tekście z tego źródła oznaczam dalej jako PS.

${ }^{28}$ Ch. Reznikoff, [Co robisz na naszej ulicy], tłum. P. Sommer, „Literatura na Świecie” 1980, nr 4, s. 316 . 
zasadzie niespodzianki bądź zawiedzionego oczekiwania. Dobrze z tego sposobu poczynania sobie z wersem - na „emocjonalnej” zwłaszcza płaszczyźnie - zdaje sprawę nieco dłuższy wiersz z ostatniego tomu poety, [Pójdę do getta]. W sposobie konstrukcji przypomina nieco typowo „diasporyczny” tekst Jozue w Sychem, w którym przedstawione zostały koleje wygnania Izraela. Oznaki powodzenia i dobrobytu, zakorzenienia się w jakiejś rzeczywistości, wydają się niepotrzebnie prowokować boską uwagę, koncentrującą się tak czy owak na Narodzie Wybranym. To, po czym można by rozpoznać Żydów, jest więc minimalizowane w trakcie narracji, jakby wyróżniające ich cechy gubili w trakcie wygnania-ucieczki, także w końcu swój dom odbudowują jedynie w mowie. Rozpoznanie ich w tej mowie staje się w końcu niemożliwe - mówią bowiem przecież we wszystkich językach; sygnatura obcości jednak pozostaje: ,[...] i spojrzał Bóg, i zobaczył Hebrajczyków,/ obywateli wielkich miast,/ mówiących po hebrajsku w każdym języku pod słońcem" (OK, 31). W późniejszym wierszu [Pójdę do getta] z Going to and Fro na podobnej zasadzie mechanizmem niosącym ze sobą niespodziankę okazuje się stopniowe zanikanie, topnienie - tego, co niesie radość albo stanowi ból, ale jednak własny - ku nieokreślonej nicości:

\author{
Zabiorą nam \\ nasze ciasta i przysmaki, \\ radosne powitania, czas miłej rozmowy, uśmiechy, \\ i dadzą nam za to \\ wzrok naszych oczu i nasze ciche myśli; \\ zabiorą nasze jęki i westchnienia \\ i dadzą nam - \\ jedynie oddech. \\ Oddychaj głęboko: \\ jakże dobre i słodkie jest powietrze $(\mathrm{OK}, 36)^{29}$.
}

Jak pisał Omer-Sherman, Reznikoff nie jest ani poetą lamentu i żałoby, ani ognistych wezwań do walki właściwych dla syjonistów. Nie odbywa żałoby po zburzonej Świątyni, ani nie myśli o Żydach jako obywatelach nowej Palestyny - raczej skupia uwagę na ich rozproszonej tożsamości i z tego stanu jako pryncypium nowoczesności w ogóle czyni zasadniczą przesłankę własnych konstrukcji poetyckich: „Czy ktoś jest w domu, czy na wygnaniu - mówi Sherman - bogactwo sensualnego świata przedstawione przez poetę Babilonu przeniknięte jest

${ }^{29}$ Omer-Sherman, odnosząc się do cytatu z jednej ze sztuk Reznikoffa, The Black Death, „The tree dies. Israel is not planted,/ Israel is in the wind", stwierdza, że dla Reznikoffa, w odróżnieniu od syjonistów, wstydzących się diasporycznej historii, „pamięć kolektywna, która ciągle powraca do tej ciemnej historii, staje się jednocześnie emfatyczną afirmacją ciągłości [żydowskiej tradycji - J.O.]" (DAZ, 153). 
przez przypadkowość, która niesie w sobie także wspomnienie o nadziei" (DAZ, 133). Ambiwalencja końcówki wiersza [Pójdę do getta] polega na tym, że nie jesteśmy w stanie zdecydować, czy nastrój utraty zostaje przez nią pogłębiony, czy też paradoksalnie zasygnalizowana zostaje niczym nieuwarunkowana, pełna przekory radość z niezakorzenienia. Nawet powietrze może być przysmakiem - dla Żyda, który w samym środku cierpienia, kłócąc się z Bogiem, znajduje w sobie cnotę głębokiego zaufania w sens boskich wyroków. A jednak u Reznikoffa to jedynie dyskretne nawiązanie do diasporycznej tradycji. Puenta wcześniejszej, lustrzanej strofy wiersza, głosi: „Ten spokój mi wystarczy;/ niech się pieklą poganie" - ale jej sens nie musi odnosić się do ponurej historii wszystkich ziemskich gett. Może stanowić także przedłużenie medytacji dotyczącej słońca: „Pójdę do getta: słońce/ na chodniku tylko godzinę lub dwie/ w południe, to mi wystarczy”. Poezję Reznikoffa można by określić jako postsekularną; wątki biblijne, związane z tradycją diasporyczną przywołuje się w niej niejednokrotnie $\mathrm{z}$ ironią, relatywizując ich religijne znaczenie poprzez rozmaite kulturalne perspektywy i odniesienia, które przyniosły wieki diasporyzmu. Wygnanie jest ideą teologiczną, a obiektywista wszak stroni od idei. Najważniejszym elementem stanowiącym odniesienie dla wierszy Reznikoffa pozostaje zawsze teraźniejszość. Mechanizm niespodzianki - niezwykłego i nieoczekiwanego odwrócenia sensów, które w przypadku takich wierszy jak Jozue w Sychem czy [Pójdę do getta] wydaje się egzotyczne i niezrozumiałe bez przywołania odpowiedniego kontekstu kulturowego - pozostaje podobny, jeżeli chodzi o z pasją tłumaczone przez Sommera miniatury. Spójrzmy na trzy, związane z charakterystycznymi dla Reznikoffa tematami. Pierwsza, [Robotnicy rozbierajacy dom], pochodzi z tomu Poems (1920) i otwiera wybór Sommera z O krok od nich. Podaję polskie thumaczenie, a za nim oryginał:

Robotnicy rozbierający dom pozostawili drzwi i schody prowadzące teraz do pustego pokoju nocy $(\mathrm{OK}, 14)$.

The house-wreckers have left the door and a staircase, now leading to the empty room of night (PChR, 19).

Niespodzianka, rozbijająca większość miniatur Reznikoffa na dwie linie melodyczne zebrane w kontrapunkt, w tym wierszu akurat nie narzuca się w zbyt oczywisty sposób, między innymi ze względu na bardzo poetyckie zakończenie - stanowiące dość rzadką w przypadku tego poety konceptualną metaforę (zdecydowanie bardziej dowartościowuje autor porównania). Dziwność świata zostaje tu więc poniekąd od razu usprawiedliwiona przez poetyzację przedstawienia, choć z drugiej strony ze względu na sposób przedstawienia wiersza - jego charakter bezstronnej obserwacji - wiemy, że całość znaczeń powinniśmy 
traktować jak najbardziej dosłownie. Piękno wiersza, poniekąd zaokrąglone metaforą, zostaje zrelatywizowane przez obecność pozostałych miniatur i wierszy: większość tekstów zamieszczonych w Poems w wydaniu Seamusa Cooneya to krótkie teksty przedstawiające biedę nie tylko żydowskich emigrantów. Ósmy wiersz został zatytułowany Ghetto Funeral, a dziesiąty, długi, narracyjny wiersz, zaczyna się w sposób bardzo przypominający omawianą miniaturę, z której rozwija się poemat: „Sleepless, breathing the black air, he heard footsteps along the street,/ and click - the street lamp was out;/ darkness jumped like a black cat upon his chest” (PChR, 20). Jej wyrazistość akcentuje niedookreślenie wcześniejszych utworów, takich jak poetycki dwuwiersz o robotnikach. Nadaje to całości Poems zasadniczo mroczny ton, jakby nie dopuszczający poetyckiego uładzenia, piękna, które wiersze Reznikoffa ze sobą niosą. A jednak nawet najbardziej dramatyczne przedstawienia takie tu właśnie są: uładzone, zwięzłe i piękne w swojej oględności. Poetyckość - zazwyczaj detalu - wynika z dyskretnie zastosowanej figury, funkcjonującej tu zawsze jak emblemat. Wiersz nie jest alegoryczny; nie sugeruje drugiego dna znaczeń odnoszących go do jakkolwiek pomyślanej zewnętrznej sfery porządkujących znaczeń; buduje swoją semantykę, chciałoby się powiedzieć podążając za zasadą filozofii Spinozy, nie transcendentalnie, ale immanentnie. Organizacja wiersza natomiast odpowiedzialna jest - jak chciał poeta - za „intensywność”, sugerującą między innymi „emocje” obserwatora. Przyjrzyjmy się wierszowi [The house-wreckers]. Ułożony został w zdanie rozdzielone na dwie linijki bez udziału przerzutni (bardzo częstej u Reznikoffa), co daje poniekąd czyste cięcie, wyłączające z metaforyzacji pierwszą część wypowiedzenia. Stanowi ona zdanie główne, nie domagające się właściwie rozwinięcia. Pierwsza linijka mogłaby być właściwie zdaniem prozy, gdyby nie wyrazista aliteracja, ujawniająca się przy głośnym czytaniu, polegająca na ciągłej wymianie otwartych, okrągłych samogłosek 'av'/ 'æv'/ 'ou' (jak w 'haus', 'hæv', 'dous' w wymo-

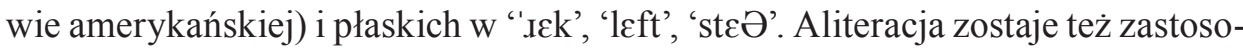
wana w kolejnej linijce, z wyjątkiem dla kończącego ją, jednosylabowego słowa 'natt'. Melodia zdania, korespondująca z rytmem (w każdym wersie mamy cztery akcenty wiersza wolnego) - jak się wydaje kołysząca, miarowa, „nocna” - odbija się od rzeczywistego sensu miniatury, który wobec tematów pozostałych tekstów, związanych z biedą pełnego emigrantów getta, może sugerować mroczną podszewkę nocnego spokoju: absurd schodów wiodących donikąd (niebo ponad głowami emigrantów jest z całą pewnością puste). Sommer - jeżeli chodzi o tak ważną dla Reznikoffa składnię - nie miał w tym wierszu do pokonania szczególnych przeszkód. Początek pierwszego wersu, „Robotnicy rozbierający dom”, naśladuje zasadę aliteracji, którą odnajdujemy w amerykańskim wierszu. Materiału języka polskiego nie udało się tu tak ,ściśle” zorganizować, stąd ginie całe, nadające miniaturze równomierność, wyakcentowanie angielskich zdań, złożonych jednak z krótszych, zawierających jedną do dwóch samogłosek słów. By dodać 
wierszowi dźwięczności polski tłumacz decyduje się na aliterację spółgłoskową w słowach „Robotnicy rozbierający” (do pewnego stopnia podejmujących angielskie "The house-wreckers have”), wzmacniając ją jeszcze decydującą o charakterze drugiego wersu aliteracją ,,prowadzące do pustego pokoju”. W końcu wiąże wersy niedokładnym rymem, nieobecnym w oryginale: „,schody” - „nocy”, podkreślając „okrągły” wygłos zaskakującej puenty wiersza, która zostaje tu jakby wyrzucona w nocną pustkę; eksponując przy tym poetyzację zwykłości, obecną w metaforze „pusty pokój nocy”. Dwa kolejne wiersze „,robotnicze” u Sommera: [Starzy mężczyźni i chłopcy] i [Dziewczęta przekrzykuja maszyny] zapewniają pierwszemu tekstowi kontekst podobny jak w zbiorze. Na podobnej zasadzie - estetycznego pęknięcia i związanej z tym niespodzianki, funkcjonują miniatury z tomu Jerusalem the Golden, drugiej książki, z której zaczerpnięto w polskim wyborze sporą garść wierszy. W wierszu [Wokót rozkopów] pomyślanym bardzo podobnie, jak [Co robisz na naszej ulicy] - u Sommera zresztą te wiersze sąsiadują ze sobą, czytamy:

Wokół rozkopów

przysiadła chmara jasnoczerwonych

lamp (OK, 22).

Polskie tłumaczenie przygotowuje niespodziankę puenty przede wszystkim poprzez ostrą przerzutnię, która - ze względu na słowa „przysiadła chmara” - przygotowuje nas co najmniej na obecność egzotycznych ptaków na środku nowojorskiej ulicy. W ciekawy sposób - poprzez podwójne przeniesienie zdania do kolejnych wersów - następuje tu najpierw sugestia obcości, przy czym miniatura przybiera formę zagadki..., która potem zostaje wyjaśniona zupełnie zwykłym zjawiskiem ,jasnoczerwonych lamp” „wokół rozkopów”. Zdanie nie wytraca paradoksalnie swojej tajemniczości w kontekście oczekiwań przechodnia, który obserwuje je okiem „obcego" - nienawykłym do zindustrializowanego, przemieniającego się nieustannie krajobrazu, w którym z całą pewnością nie czuje się zadomowiony - choć przecież usiłuje w nim przecież pomieszkiwać, oswajając, tłumacząc go sobie i objaśniając poetyckim słowem. Reznikoffowski podmiot zwiedza Nowy Jork niczym Alicja Krainę Czarów - oczywiście pod warunkiem, że uznamy, iż mamy tu do czynienia z raczej smutną bajką, dla dorosłych. Angielski oryginał nieco inaczej niż polskie tłumaczenie rozgrywa konstrukcyjne emocje:

About an excavation

a flock of bright red lanterns

has settled (PChR, 99). 
Tutaj całe poruszenie właściwe dla miniatury osadzone jest w czasowniku czasu present perfect, przeszło-teraźniejszego, niosącego ze sobą znaczenie czegoś, co wydarzyło się dopiero co, a czego efekty właśnie widać - jakby latarnie przed chwilą obsiadły rozkop, niczym stado kolorowych ptaków. Nieobecność tego czasu w polszczyźnie skazuje tłumacza na konieczność rozdzielenia członów zdania tak, aby to podmiot zdania, rzeczownik ,lampy”, stanowił odwlekane poprzez przerzutnie wyjaśnienie zagadki. Stanowi to zabieg prostszy i mniej subtelny niż w wierszu Reznikoffa, ale w polskim tłumaczeniu równie interesujący. Swoista „egzotyczność” miasta, efekt obcości związany albo z punktem widzenia przechodnia, albo z „obcością” uwewnętrznioną, niesioną przez sam podmiot, uzyskuje komentarz - przedłużenie w postaci kolejnych tekstów. Jeden, dopowiadający wyraziściej to, co niedopowiedziane w miniaturze o lampach: „This smokey winter morning -/ do not despise the green jewel shining among the twigs/ because it is the traffic light” (PChR, 102); „W ten zadymiony pranek zimowy -/ nie gardź zielonym klejnotem błyszczącym wśród gałązek/ gdyż jest to światło skrzyżowania" $(\mathrm{OK}, 27)$ - uprzytamnia zasadniczy mechanizm kontrapunktujący większość miniatur, a także i wielu innych wierszy, który zasygnalizowany tylko został w cytowanych przeze mnie tekstach. To antyteza pomiędzy naturą, z której wygnany został miejski człowiek i towarzyszący temu wgląd w zindustrializowany świat, który z takim trudem musi budować, na podstawie z konieczności błędnych przesłanek. Swoiste, w bardziej diasporycznym tonie utrzymane podsumowanie tego wątku poezji Reznikoffa, może stanowić przetłumaczony przez Sommera wiersz, również z Jerusalem, [Wrośnięte w dachy]: „Wrośnięte $\mathrm{w}$ dachy, z dymem pośród chmur - / kominy fabryk - nasze cedry Libanu" (OK, 24).

Sommer - odnosząc się do swoich tłumaczeń z Reznikoffa - próbuje oddać swoje doświadczenie z jego poezją poprzez kategorię ,westchnienia przechodnia":

Przechodzień intensywnie patrzył, przystawał, zapamiętywał scenę, może notował zdanie albo frazę. Poeta dokładał starań, żeby żadna z obserwacji nie obnosiła się ze sobą - już lepiej, żeby zamieniła się w westchnienie [...] o kształcie wiersza decyduje dopiero to, jak kominy z dymem [Sommer odnosi się tu do wiersza [Wrośnięte $w$ dachy] - J.O.] zwiąże w całość składnia. Składnia, a więc intonacja, a więc i rytm. Jedno ze spacerowych westchnień Reznikoffa (OK, 533).

Wszystkie teksty w zbiorze - zarówno epigramatyczne, jak i te ciążące w stronę narracyjnego poematu - napisane są w takiej samej, w pewnej mierze prozatorskiej manierze, co rzuca się w oczy przede wszystkim, kiedy autor pozwala sobie na dłuższą linijkę. Poddane są one intonacji i składni zdania mówionego, sprawiają więc wrażenie powolnie płynącej narracji, prawie przezroczystej, 
nie skupiającej uwagi czytelnika za pomocą zbyt wielu figur czy ozdobników - wyjątek stanowi tu zasadniczy dla tej poezji zabieg: przerzutnia. Składnia Reznikoffowskich, pociętych na wersy zdań wydobywa efekt niespodzianki, podkreślając obcość spojrzenia zdystansowanego podmiotu. Śladem jego emocji pozostaje właśnie decyzja konstrukcyjna. Także w wierszach samego Sommera, pomimo tego, że zazwyczaj mamy poczucie pewnego rodzaju zasiedziałości w obiektywizowanym poprzez poetyckie działania krajobrazie, istotną sprawą pozostaje właśnie odróżnienie porządku poetyckiego, który wypadać ma w wierszu całkowicie naturalnie od zwykłości języka oswojonego przez rozmaite hierarchie czy konwencje przedstawiania. Energia stojąca za taką koncepcją poezji pozostaje jak najbardziej awangardowa; trudno jednak oprzeć się skojarzeniom z poetyką Reznikoffa, kiedy czytamy takie obiektywistyczne wiersze z Piosenki pasterskiej, jak Wczoraj czy Rano na ziemi; albo miniatury z Wierszy ze stów, napisane z Reznikoffowskim temperamentem, jak Pewniki: „Klony kładą gałęzie na ziemi./ Chyba coś się stało” czy Ptak: „Zobaczy wreszcie, co jest po drugiej stronie/ Wału Miedzeszyńskiego!'”30 Tak naprawdę jednak zdecydowane znamię „reznikoffowskości” noszą w sobie narracyjne utwory poświęcone zmarłym z niedawnych Dni i nocy. Kontynuując swoje rozważania na temat wiersza What are you doing in our street..., Sommer z rezerwą odnosi się więc do zalecenia dotyczącego „dominanty semantycznej” jako gwarantującej poprawność tłumaczenia, która została wprowadzona przez Barańczaka ${ }^{31}$. Według tłumacza nie może ono zostać utrzymane, kiedy cały ciężar znaczenia wiersza powiązany zostaje ze składnią: ,„...] zdanie jako podstawowy element struktury wiersza bywa znaczeniowo (ale nie tylko znaczeniowo) mniej przewidywalne, niż definicja dominanty semantycznej - zarezerwowanej bodaj dla wiersza o regularnej prozodii - gotowa by była przyznać" (PS, 223). Zdanie, jego intonacja i rozłożenie akcentów w linijce, brzmienie wyrazów - ciążące ku aliteracjom, czasami niedokładnym rymom, to zatem podstawowe elementy wiersza, za pomocą których można oddać istotę poetyckiego myślenia Reznikoffa; oczywiście nie w pełni - składnia polszczyzny, jak już pisałam, jest mniej elastyczna, stąd szczególnie ciekawe są metody, za pomocą których Sommer usiłuje przygody Reznikoffowskiej składni przełożyć. Podobnie jak w przypadku wiersza o jasnoczerwonych lampach, jedyny, krótki tekst z tomu Separate Way: „Przestraszył mnie/ chroboczący po trotuarze/ brunatny liść dębu” (OK, 33) - prawdopodobnie wybrany ze względu na kontekst dla Płaczu kobiet żydowskich nad Tammuzem, w którym „,iemne liście dębu porzuciły Ur i stały się tułaczami” z puentą: „A to rozsypane po chodnikach -/ kruche szkielety liści” (OK, 25) - opiera się na odwróceniu zabie-

\footnotetext{
${ }^{30}$ P. Sommer, Po ciemku też (wiersze z książek), WBPiCAK, Poznań 2013, s. 294-295.

${ }^{31} \mathrm{~S}$. Barańczak, Mały, lecz maksymalistyczny Manifest translatologiczny, w: tegoż, Ocalone w tlumaczeniu, Kraków 2009. Sommer odnosi się do publikacji tego tekstu Barańczaka w 3 numerze „Tekstów Drugich” z 1990 roku.
} 
gu składniowego. W angielszczyźnie możliwa jest ucieczka od przedmiotu jako punktu ciężkości semantycznej wiersza, w kierunku funkcyjnego czasownika, a co za tym idzie - możliwe jest stworzenie wiersza, który pozostaje w dużej mierze zdramatyzowany, stanowi akcję obserwacyjną, nie zaś akt informacji. W polskim wierszu pozostaje to dużym problemem. W polszczyźnie czasowniki wytracają swoją płynność unieruchomione przez sufiksy, które determinują skupienie uwagi czytelnika na przedmiocie; stąd automatycznie polski czytelnik o wiele większą wagę wiąże z przedmiotową, tematyczną sferą przedstawienia, „obiektywistyczny” tekst postrzegając wręcz jak obrazek. O wiele większą wagę przywiązuje się u nas w przypadku eksperymentalnej poezji do brzmienia słów i ich słowotwórczego potencjału. Sommer, gospodarując polską składnią, musi mieć świadomość, że punktem ciężkości zdania: „A brown oak leaf/ scraping the sidewalk/ frightened me" $(\mathrm{P}, 155)$ dla polskiego czytelnika musi być właśnie „obrazkowy” „liść dębu”, nie zaś, jak w angielskim, gerundium „scraping” i czasownikowa puenta „frightened me”. Angielska puenta jest niezwykle intensywna ze względu na umieszczenie na końcu wersu wybijającego nas z rytmu zdania zaimka „me”. Polski tłumacz decyduje się przestawić kolejność członów zdania budujących efekt zawieszenia sensu i niespodzianki. Całość zostaje skupiona na ujawnionym w ostatniej chwili „liściu dębu”, który poprzez wcześniejsze określenia - inicjalne, więc prawie tak samo ważne, co w Reznikoffowskiej puencie „przestraszył mnie” i odczasownikowy przymiotnik „chroboczący” - może sugerować, że będziemy mieli do czynienia co najmniej z żywym stworzeniem, szczurem, myszą lub ostatecznie kuną - ale nie z czymś tak niewartym uwagi, jak suchy liść. Powiedzieć można, że poprzez odwrócenie szyku zdania, które ma na celu podtrzymanie intensywności wiersza, związane $\mathrm{z}$ angielską składnią, dochodzi do swego rodzaju przekładu emocji - funkcjonujących właściwie poza tekstem, jako coś, „,co zostało przeżyte”, nie jako właściwa treść przekazu.

Sommer dość rzadko (poza wierszami autotematycznymi) mówi na temat własnych preferencji artystycznych, ale już zdanie wypowiedziane w rozmowie z Barbarą Łopieńską zdradza twórcę o „obiektywistycznym” temperamencie. Poeta stwierdza, jakby podążając za (niekoniecznym) precedensem ustanowionym przez Obiter Dicta:

Mogę tylko powiedzieć, że mnie w pisaniu - tak wiersza, jak i czego innego - najbardziej obchodzi detal i właśnie melodia, powiedzmy melodia zdania. [...] Ja się chyba najbardziej czuję obserwatorem - niekoniecznie krytycznym - w każdym gatunku, przy którym dłubię. A więc i w pisaniu wierszy, i krytyki, może zwłaszcza krytyki, i w przekładach. Kiedy piszę wiersz, bardziej pewnie niż inne rzeczy interesuje mnie obserwowanie języka w trakcie jego stawania się i wydobywania z siebie melodii... Utarło się uważać, że wiersz czemuś służy - jeśli nie polityce, to przynajmniej autorskiemu wyrażaniu siebie. Ale wierszowi często bardziej chodzi o to, co i jak wyrazić 
- o ustawienie własnego głosu... Wiersz może wówczas przysłużyć się nawet językowi - w tym sensie mówię o roli zdania i melodii. W pisaniu najważniejszy jest rejestr i ton. W przekładzie zresztą też (UWB, 11-12).

Nawet jeżeli polski tłumacz decyduje o pominięciu długich poematów, bardziej otwarcie przedstawiających przesłanki dla dwóch zasadniczych motywacji, napędzających Reznikoffowskie przygody składni - obcości i pełnego współczucia spojrzenia - to emocjonalne znamię noszą właściwie wszystkie wiersze żydowsko-amerykańskiego poety. W stylu poetów, którzy odnaleźli się w amerykańskiej kulturze poza judaizmem i którzy wyrażają się w nowym, „rodzimym” języku, wytworzony zostaje pewien modus mówienia, który nosi w sobie wyczuwalny element obcości, powiązany z tożsamością siebie jako „Innego”, jak to ujmuje w swojej poświęconej Reznikoffowi książce Fredman. Razem z poczuciem niezadomowienia w jakimkolwiek języku pojawia się kompulsywna potrzeba korygowania wiersza, powiązana z pragnieniem językowej „czystości” i jasności ekspresji: swoista hiperpoprawność cudzoziemców, którzy zawsze mają tendencję do popadania w błędy. Przymus kontroli wyrazu przynosi nawyk ciągłego sprawdzania własnych tekstów, zakładającego ciągłą redukcję znaczeń, która daje rezultat w postaci wierszy zwięzłych i jasnych, „obiektywistycznych”. Skrupulatna uwaga, jaką obdarza się poetycki detal z punktu widzenia Zukofsky’ego stanowi sygnał autorskiej „szczerości”. Przez Reznikoffa była ona rozumiana w sposób zgodny z ideą wierności tłumaczenia wobec kontekstu: ludzi, ich języka i przypadkowego sposobu, w jakim go akurat użyto. Temu ostatniemu towarzyszy szczególna czujność, jeśli chodzi o wszelkie praktyki społecznego wykluczenia i współczucie wobec wszelkiego rodzaju wykluczonych. Sommerowa lekcja tłumaczenia wierszy Reznikoffa - zamieszczona najpierw w Artykułach pochodzenia zagranicznego, później nieco skorygowana w Po stykach - stanowi podobny przykład skrupulatnej czytelniczej uważności, niezwykle czułej, jeśli chodzi o detal i specyfikę osobniczego języka; czyjegoś sposobu odczuwania świata, który uzyskuje swoistą kondensację w miniaturze - najlepszym przykładzie poetyckiej praktyki autora Jerusalem the Golden. Taka uważność wymaga właśnie „obserwacyjnego" wycofania podmiotu, tak by w jak najmniejszym stopniu - jedynie poprzez układ zdania, intonację i składnię stanowiące odbicie dyskretnie ujawniającej się emocji - ustanawiał on filtr modyfikujący nie przedstawienie, a tłumaczenie ,zobiektywizowane”.

Autor Po ciemku téz w wielu miejscach zdradza się z rozmaitymi pokrewieństwami, świadczącymi o tym, że obiektywizm żydowsko-amerykańskiego poety, będącego od lat dwudziestych, trzydziestych jednym z najwybitniejszych przedstawicieli awangardowej, nowojorskiej bohemy, to bliska mu filozofia. Pewnym elementem łączącym go światopoglądowo z ,pograniczną” sytuacją poetów obiektywistycznych mogłaby być wczesna inspiracja poezją i postawą Jerzego 
Ficowskiego - w polskiej przestrzeni literackiej zajmującego wszak podobne miejsce, co żydowsko-amerykańscy awangardziści jako przedstawiciele „pomniejszego" nurtu nowoczesności i - jak chcieli co znamienitsi krytycy - jedynie naśladowcy Poundowskiego imażynizmu. Rakosi, Oppen, Zukofsky i Reznikoff pozostawali długo na straconej, lekceważonej i marginalizowanej pozycji wobec głównego nurtu modernizmu - właśnie ze względu na swoją żydowskość, jak sugerują Blau DuPlessis i Quartermain. Ficowski, w pewnym sensie poetycki mentor Sommera - przewodnik po poezji Leśmiana, prozie Schulza - był w Polsce kulturowo w bardzo podobnej sytuacji, znajdując się pomiędzy dwoma tradycjami kulturowymi i w żadnej z nich chyba nie czuł się jak w domu. U Ficowskiego podobnie i z podobnych przyczyn - ważnym elementem organizującym poezję jest zadziwienie ciągłą innością świata, przejawiające się przede wszystkim w samym języku z jednej strony i wielką sympatią dla wszystkiego, co obce - z drugiej. W posłowiu do wyboru wierszy Ficowskiego Wszystko to czego nie wiem Sommer, interpretując pierwszy wiersz Odczytania popiołów - rozpoczynający się od zdania „nie zdołałem ocalić/ ani jednego życia” - traktując go jako przykład charakterystycznej dla poety „odwrotki”, „po nowemu określającej status wszystkiego", stwierdza:

Okazuje się mianowicie, że to, co tuż po wojnie, na różne sposoby, ważne było dla Tadeusza Różewicza i Czesława Miłosza jako „ocalenie” - u Ficowskiego, mówione trzydzieści lat później ze stanowiska pełnej dojrzałości medytującego ,ja”, wraca i okazuje się ważne jako „nieocalenie”. [...] Nieodnotowanie tak głębokiej odmienności w kwestii uchodzącej za podstawową, zwraca na siebie uwagę i z tej racji, że ów prawie cały, pisany przez ponad ćwierć wieku, cykl stanowi przykład całkowicie sklarowanego już języka, który odnawia zarówno ton medytacji, jak i kształty elegii ${ }^{32}$.

W cytowanej już rozmowie dla „Kwartalnika Artystycznego” sprawa ta wypada jeszcze jaśniej:

['ocalenie' jako podstawowa kategoria polskiej literatury powojennej - J.O.] dominowało przez kilkadziesiąt lat - $\mathrm{i}$ ten stereotyp przerodził się $\mathrm{w}$ jakiś okop i bastion jednocześnie, w przeświadczenie, że to, co „nie ocala narodów”, jest bez znaczenia. [...] A co chociażby z kategorią nieocalenia i nieocalonymi? Już to najprostsze, odwrotkowe przeciwstawienie wyskakiwało ponad ideologiczne i krytycznoliterackie możliwości epoki - już się nie mieściło. „Nie zdołałem ocalić ani jednego życia”

${ }^{32}$ P. Sommer, Wszystko, co trochę wiem (O poezji Jerzego Ficowskiego), w: J. Ficowski, Wszystko to, czego nie wiem, wybór i posłowie P. Sommer, Fundacja „Pogranicze”, Sejny 1999, s. $181-182$. 
- zaczyna pewien swój wiersz Jerzy Ficowski, który jest w Polsce poetą nadal zapoznanym, bo u niego przygód języka również nie udało się zauważyć. Chyba muszę się pogodzić z myślą, że życzliwi koledzy wysłali go na Syberię dobrych intencji. Ile to wygody: ot, po prostu zacności człowiek - Cyganami się zajmował i Żydami, i Schulzem, i Papuszę wynalazł [...], ale czy największy prawodawca nie zadekretował, że „Dobry człowiek nie nauczy się podstępów sztuki”? I czy kto słyszał, żeby prawdziwy poeta tak bardzo zajmował się innymi? $?^{33}$

Sommerowa poezja, tak jak poezja amerykańskiego i polskiego poety podobnie często, choć może nie w fanfarach wielkiej dwudziestowiecznej historii, włącza ,innych” w swoje przedstawienia, a jako zasadniczy przedmiot zainteresowania autora przedstawia wszelkiego rodzaju - kulturową i językową - pograniczność. Języki, które budzą zainteresowanie Sommera, to języki wyróżniające się szczególnym ,ożywieniem”, które zawdzięczają energii emancypacyjnej; z podobnych źródeł płynie wyrażana przez niego sympatia w stosunku do ożywczych zmian, wprowadzanych przez poetów przełomu lat osiemdziesiątych i dziewięćdziesiątych, stroniących od wzniosłego, często napuszonego języka poezji polskiego mainstreamu. W rozmowie dla „Kwartalnika Artystycznego", Sommer, wypowiadając się na temat swojej sympatii dla Kawafisa - w Polsce rozpoznanego dzięki tłumaczeniom Kubiaka raczej jako wysokomodernistyczny poeta - sprawę przemawiania obcym językiem, z marginesów kultury, ciągnie właśnie aż do ostatniego czasu, ze zmarginalizowanego języka mniejszości czyniąc sprawę w historii liryki uniwersalną:

Kawafis rewolucjonizował język greckiego wiersza „łagodnie”, ale rozsadzał zastarzały paradygmat, więc budził. Budził niechęć tym bardziej, że mówił spoza centrum - mówił z Aleksandrii, myślał z Aleksandrii, chodził do kawiarni w Aleksandrii, chodził do łóżka z chłopcami z Aleksandrii, i z Aleksandrii „psuł” tym niechętnikom i sztywniakom z kontynentalnej Grecji grecki język. W dodatku bardzo go obchodziła poezja, która powstawała po angielsku i po francusku. [...] Przypomina to niezbyt odległe batalie wokół poezji na wyspach tzw. brytyjskich, z ich poetyckimi obrzeżami i nacechowanymi lokalnie akcentami, które nagle przestały być mniejszościowym marginesem. A także jeszcze mniej odległe batalie w Polsce - kiedy to „niechętne centrum” mówi „aspirantom z obrzeży”, wielorako rozumianych obrzeży, coś w rodzaju: ,W żadnym wypadku, kto wy w ogóle jesteście, wracajcie sobie skąd przyszliście, a aspirantom ani się śni” (KA, 39).

${ }^{33}$ Co robi zdanie?, s. 45. 


\section{Bibliografia}

Artykuty pochodzenia zagranicznego, wyb. i przekł. Piotr Sommer, Wydawnictwo Marabut, Gdańsk 1996.

Bilczewski Tomasz, Komparatystyka i interpretacja. Nowoczesne badania porównawcze wobec translatologii, Wydawnictwo Universitas, Kraków 2010.

Blau DuPlessis Rachel i Quartermain Peter, Introduction, w: The Objectivist Nexus. Essays in Cultural Poetics, red. Rachel Blau DuPlessis, Peter Qartermain, University of Alabama Press, Tuscaloosa and London 1999.

Co robi zdanie?, Piotr Sommer w rozmowie z Zofią Zaleską, „Kwartalnik Artystyczny” 2015, nr 3 , s. $36-57$.

Dembo Lawrence Sanford, An Interview with Charles Reznikoff, „Contemporary Literature” 1969, nr 10; za źródłem w wersji elektronicznej: http://www.jstor.org/stable/1207760 [dostęp: 10.11.2014].

Derrida Jacques, Wieże Babel, przekł. Adam Dziadek, w: Współczesne teorie przekładu. Antologia, red. Piotr Bukowski, Magda Heydel, Znak, Kraków 2009.

The Ear of the Other. Otobiography, Transference, Translation (Texts and Discussions with Jacques Derrida), red. Christie McDonald, Schocken Books, New York 1985.

Fredman Stephen, A Menorah for Athena. Charles Reznikoff and the Jewish Dilemmas of Objectivist Poetry, University of Chicago Press, Chicago and London 2001.

Hindus Milton, Epic, Action-Poem, Cartoon. Charles Reznikoff's Testimony: The United States 1885-1915, w: Charles Reznikoff. Man and Poet, National Poetry Foundation, University of Maine at Orono 1984; za źródłem w wersji elektronicznej: http://www.english.illinois.edu/ maps/poets/m_r/reznikoff/testimony.htm [dostęp: 9.10.2015].

Jarniewicz Jerzy, Tłumacz jako twórca kanonu, w: tegoż, Gościnność słowa. Szkice o przekładzie literackim, Znak, Kraków 2012.

Literatura jest ttumaczeniem, rozmowa Jerzego Illga, Bronisława Maja, Mariana Stali z Ryszardem Krynickim, Czesławem Miłoszem i Piotrem Sommerem, „NaGłos” 1993, nr 11, s. 13-27.

O krok od nich. Przekłady z poetów amerykańskich, wyb. i przekł. Piotr Sommer, Biuro Literackie, Wrocław 2006.

Omer-Sherman Ranen, Diaspora and Zionism in Jewish American Literature. Lazarus, Syrkin, Reznikoff, and Roth, Brandeis University Press, Hanover and London 2002.

The Poems of Charles Reznikoff 1918-1975, red. Seamus Cooney, Black Sparrow Books, Boston 2005.

Pound Ezra, A Retrospect, w: tegoż, Pavannes and Divisions, Knopf, New York 1918; https:// archive.org/stream/cu31924021664408\#page/n127/mode/2up/search/a+retrospect [dostęp: 3.01.2018].

Reznikoff Charles, Graffiti 67 wierszy z lat 1920-1975, przekł. Piotr Sommer, SDK, Sanok 1991.

Sommer Piotr, Po ciemku też (wiersze z książek), WBPiCAK, Poznań 2013.

Sommer Piotr, Ttumaczac miniatury Charlesa Reznikoffa, w: tegoż, Po stykach, s. 220-240. Słowo/Obraz Terytoria, Gdańsk 2005.

Sommer Piotr, Ucieczka w bok (Pytania i odpowiedzi), Biuro Literackie, Wrocław 2010.

Sommer Piotr, Wszystko, co trochę wiem. (O poezji Jerzego Ficowskiego), w: Jerzy Ficowski, Wszystko to, czego nie wiem, wyb. i posłowie Piotr Sommer, Fundacja „Pogranicze”, Sejny 1999.

Zukofsky Louis, Sincerity and Objectification. With a Special Reference to Charles Reznikoff, „Poetry” 1931, nr 5, s. 272-285, http://www.jstor.org/stable/20577923 [dostęp: 10.11.2014]. 


\title{
Joanna Orska \\ "Being apart seems most interesting to me" - Charles Reznikoff and Piotr Sommer's Translations
}

\begin{abstract}
(Summary)
The focus of this paper is the Polish translation of Charles Reznikoff poetry. Firstly, there goes an overall characteristic of the work by the American writer, whose conceptions became a core of the objectivist group-program of young poets connected to the Jewish diaspora in the 1930's. Later, the main focus shifts to the conditions and presumable reasons for certain choices made by Piotr Sommer, Reznikoff's Polish translator. Sommer's choice - focusing predominantly on Reznikoff's poetic miniatures - sheds light on the translator's artistic preferences. Those poems by Reznikoff that have been translated into Polish do not carry as rich a historical, social, and cultural context - so important for an artist of the Jewish background - as his longer works, saturated with the religious allusions. However, Sommer's translator's craft - full of care and responsive to detail - allows his translations to frequently signal the strangeness and liminality of the passer-by subject, roaming the streets of New York.
\end{abstract}

Keywords: objectivism; avant-garde poetry; translatology; diasporism; Charles Reznikoff, Louis Zukofsky; Piotr Sommer; interpretation strategies; poetic miniatures. 